\title{
Onde Depara o Novo? Prefeituras, festas e políticas culturais no sertão mineiro
}

Gustavo Meyer $^{\mathrm{a}}$

A partir de olhares da antropologia da política e do desenvolvimento, busco analisar neste artigo alguns entrelaçamentos entre a 'área da cultura', política e desenvolvimento nos municípios de Arinos e Chapada Gaúcha, Minas Gerais. Elementos culturais, como 'movimento' e 'personalismo', participam ali como diretrizes para que atores locais heterogêneos, com interesses, visões e projetos de mundo concorrentes, operem um circuito de festas, valendo-se de políticas públicas culturais distintas para adquirirem margem de manobra e duelarem sentidos na 'área da cultura'. A capacidade de alguns em subverter - provocando uma tensão despolitização-agência - e a habilidade de outros em tecer alianças supralocais e inovar por meio de articulações em rede são mediadas por políticas públicas, que impõem ali racionalidade particular, mas que também proveem recursos importantes para a disputa. Desse jogo, apreende-se a multiplicidade do próprio Estado que, combinada com ações locais contestatórias, abre espaço potencial para a redistribuição de poderes.

Mudança social, Política cultural, Desenvolvimento, Antropologia da política.

Quando eu transitava pelas rodoviárias de algumas pequenas cidades no sertão ${ }^{1}$ de Minas Gerais, chamava minha atenção a diversidade de cartazes anunciando festas nessa região. De modo marcante,

a Professor Adjunto da Universidade Federal dos Vales do Jequitinhonha e Mucuri (UFVJM), coordenador do Laboratório de Sociologia, Antropologia e Extensão Rural/ UFVJM. Email: meyer_gustavo@yahoo.com.br. 
os anúncios evidenciavam algum conteúdo religioso, ao passo que, simultaneamente, me faziam construir uma imagem mental de eventos demasiadamente eufóricos, regados ao álcool, com som em volume alto, bandas musicais e canções sexualizadas, além de muita poeira. Evidentemente, os cartazes remetiam a experiências prévias que eu havia tido com festas que, até então, me pareciam similares àquelas. Se isto denunciava algum preconceito de minha parte, não diminuía, no entanto, a curiosidade para com a expressividade de tais festas que aqueles cartazes pareciam demonstrar. Nesses tempos, à época de 2012-2014, eu me dirigira à região, mais intensamente aos municípios de Arinos e Chapada Gaúcha, para realizar uma etnografia que daria lastro a minha tese de doutorado. Eu almejava problematizar noções de desenvolvimento, estranhando concepções modelares, formuladas a priori, argumentando que ideias, mensagens, narrativas e práticas de desenvolvimento rural podiam ser forjadas e operadas em arenas não convencionais - com alguma distância da agricultura - envolvendo agentes e atores tantas vezes invisibilizados. Enfim, eu estava a adotar uma postura antropológica, quando me esforçava, perante meus pares - congregados na área multidisciplinar do desenvolvimento rural -, em posicionar o desenvolvimento rural fora de um campo especializado ou conformista. Particularmente, eu buscava apreender operações de desenvolvimento, 'rural', imersas em um campo que eu nomeava, não sem incômodo, como sendo artístico-cultural².

Não resta dúvida que desenvolvimento é um conceito controverso e polissêmico que, de formas variadas, encerra por projetar desejos nas pessoas (Escobar 1995; De Vries 2007) e, não raro, emplacar ideias-força (Ribeiro 2008). O uso da palavra desenvolvimento frequentemente evoca o espelhamento de um cenário futuro, de um horizonte de mudança; e esta é uma das razões pelas quais se fazem associações entre desenvolvimento e mudança social no plano acadêmico. Desenvolvimento faz projetar teleologias variadas e faz operar ambientes de disputa, em particular quando há recursos envolvidos nesses projetos de futuro. Assim, tal ideia, de modo sem precedentes, 
parece abrigar, organizar e potencializar esforços para a construção da realidade, esforços estes direcionados em sentidos múltiplos, conflitantes e tantas vezes concorrentes.

Ao se abandonar uma perspectiva totalitária de desenvolvimento - de querer dizer onde e como este ocorre, aonde conduz, quais atores envolve e quais áreas, campos ou domínios perpassam - direciona-se o olhar à forma como atores locais formulam e internalizam signos e práticas de desenvolvimento. Mensagens, tantas vezes advindas de 'uma' modernidade, hegemônica, são atualizadas e repaginadas em mundos sociais particulares (Arce \& Long 2000). Trata-se de importante fonte de contestação, que coloca discursos, imagens e práticas em concorrência de atribuição de significados a elementos passados, presentes e futuros. $\mathrm{O}$ acionamento de representações neste âmbito exige o reposicionamento constante de atores em jogo, gerando interfaces sociais e epistêmicas, as interfaces de desenvolvimento nos termos de Long (2007). Daí que interesses conflitantes forjam coalizões, margens de manobra e, não raro, disparam movimentos de reposicionamento social. Interessa à antropologia, em particular, o processo pelo qual os atores sociais recorrem à cultura e à imaginação para gerar esta margem de manobra, assim como investigar como diferentes valores, práticas e narrativas sobre o(s) mundo(s) 'moderno'(s) se interpenetram e interagem no cotidiano de grupos com experiências socioculturais diversas.

A despeito do esforço de tentar compreender a realidade recorrendo unicamente a este eixo nomeado desenvolvimento, na prática investigativa daquilo que me propus, tive que adentrar, empírica e teoricamente, o domínio da política, ou, a 'área da política', como diriam no sertão mineiro em questão. Tal qual o desenvolvimento, a política é manejada por pesquisadores como 'tipos de espaços', 'analíticos' e ao mesmo tempo 'objetivos', considerando que estes são constituídos por atores sociais que compartilham linguagem e dividem poder. Acrescenta-se a isto o fato de que política constitui categoria operatória da realidade que não raro aparece entremeada a dimensões 
variadas da vida; se política, economia e religião se interpenetram e não podem ser compreendidas isoladamente sem expressivos prejuízos analíticos, ocorre algo análogo entre política e desenvolvimento, este constituindo categoria crescentemente acessada para ver e dividir o mundo. Conforme disse Peirano (1997), a inspiração antropológica sugere 'reunir sempre'... Daí que as noções de política atribuídas pelos atores sociais são diversas - motivo pelo qual se cunha a termo antropologia 'da' política (Goldman 2006; Palmeira \& Barreira 2006), ao invés de antropologia política. Enfim, tomo aqui a categoria 'política' de forma etnográfica, evitando pretensões essencialistas ou conformistas. E, nesse sentido, estou a falar como se fosse da própria ideia de desenvolvimento.

O texto que segue está inspirado em uma antropologia da política, no qual busco refletir sobre esta não apenas preocupado em não ficar preso a definições modelares, mas no intuito complementar de apreender as práticas classificatórias dos agentes sociais em cena (Palmeira \& Barreira 2006). É importante acrescentar que, contudo, em geral há algo de bastante objetivo à política, algo de relativamente comum aos contextos variados: ela constitui meio de acesso a recursos públicos em que o político é o mediador, e "esse fluxo de trocas é regulado pelas obrigações de dar, receber e retribuir", seguindo uma "lógica da dádiva” (Kushnir 2007:164). Então, não raro, o pesquisador fica defronte da tarefa de processar laços pessoais e prática de favores em jogo (Palmeira \& Barreira 2006), podendo, a partir disso, buscar entender o significado polissêmico da política, particularmente quando ele considera, para além da trama 'tradicional' em determinado local, a incidência de políticas públicas formuladas em condições relativamente externas. Nesse movimento, interessa igualmente a percepção de como emergem e são reproduzidas relações de poder e como os agentes sociais experienciam a política, seja a 'tradicional', a 'externa' ou a relação entre estas duas e outros elementos, tendo como fundo a ideia de que a sociedade é heterogênea e constrói a realidade de formas variadas. Essa é uma combinação possível para se investigar, 
por um lado, como são atribuídos significados aos objetos e práticas da política e, por outro, para se perceber como isso permite refletir sobre contextos sociais mais amplos (Kuschnir 2007). Por fim, se a política aciona a distribuição de recursos e um jogo de oposições-ligações entre atores sociais, envolve também representações partilhadas, elaborações históricas, valores, ideais e sociabilidades específicos. É nesse sentido que se torna possível apreender a política como algo sui generis (Peirano 1997).

Em outros termos, estive a seguir um dado 'desenvolvimento', supostamente duelado em um campo artístico-cultural, e deparei-me com um espaço reconhecido pelos atores sociais em cena como um terreno um tanto 'político'. Dessa forma, neste artigo procuro analisar alguns enlaces entre desenvolvimento - que em larga medida aparece associado a projetos de mundo e as disputas e construções sociais associadas - e política(s), mediados por cultura nos municípios de Arinos e Chapada Gaúcha, sertão mineiro ${ }^{3}$. Em razão de eu ter escolhido as festas regionais como entrada investigativa, opto pela sequência de explorar adiante primeiramente as particularidades locais dessas festas, depois evidenciar a inércia - grosso modo, de querer fazer festas dentro de uma 'área da cultura' - inerente à ação das prefeituras quando novas políticas culturais oficiais são acessadas e operadas localmente e, por fim, elucidar como essas mesmas políticas e as festas são manejadas no embate entre atores locais com projetos de mundo concorrentes. Em razão deste último ponto, as informações que apresento a seguir devem ser entendidas, em parte, como produto da emergência de uma rede de atores locais que coloco, mais a frente, enquanto 'contestatórios' do status quo; atores organizados e reconhecidos enquanto sociedade civil ou movimento social que encerram por concorrer com as prefeituras. Trata-se de uma rede bastante coesa, cujo discurso valoriza a cultura da 'roça' e recorre a uma narrativa literária inspirada no escritor João Guimarães Rosa, em processo de retroalimentação de uma narrativa nativa marginal (Meyer, Marques \& Oliveira 2016). Esta, por sua vez, faz contraponto à ideia de desenvolvimento hegemô- 
nica fundada na 'modernização do campo' e é forjada, particularmente, em eventos e processos artístico-culturais emblemáticos na região que circunda e envolve Arinos e Chapada Gaúcha. A hegemonia em questão inclui ou se alia aos modos locais de fazer política, por sua vez praticados largamente por representantes das prefeituras.

\section{Festas, folias e movimento}

Estando em Arinos ou em Chapada Gaúcha, é possível observar no período entre junho e outubro de cada ano, o anúncio de diversas festas, seja por meio de cartazes ou a partir de conversas corriqueiras. Elas ocorrem ali e nos municípios circunvizinhos e representam regionalmente uma espécie de comemoração anual de cada um dos vários municípios que, ao oferecerem a festa, ficam inscritos em uma espécie de 'circuito regional de festas', extrapolando o espaço desses dois municípios. Muitas delas têm origem católico-religiosa e foram inauguradas, em grande medida, em comemoração a algum(a) santo(a) padroeiro(a) do respectivo município. Outra parte surgiu sob o viés mais comemorativo que religioso, mas como desdobramento regional dessa religiosidade. Essas festas, as 'festas das cidades', são marcadas por seu conteúdo de 'cultura de massas', constituindo oportunidade à execução de grandes shows populares oferecidos pelas prefeituras, parte deles caracterizados como 'funk', 'arrocha', 'sertanejo', 'forró de teclado' etc. Compõem também elas, de modo quase que generalizado: um conjunto de comerciantes itinerantes ${ }^{6}$, que percorre todo o circuito; o consumo exacerbado de álcool como instrumento de socialização e euforia e; na maioria dos casos, a dimensão religiosa, expressa em termos de espaço e tempo reservados ao sagrado, em oposição ao profano. $\mathrm{O}$ circuito regional de festas está representado na Figura $1^{7}$.

Essas festas, pela frequência e quantidade que ocorrem, demonstram significância econômica, pois movimentam um verdadeiro mercado itinerante, onde são vendidos artigos consumidos ao longo de todo o ano por parte considerável da população local: roupas, uten- 
sílios domésticos diversos, brinquedos, temperos, alimentos, equipamentos eletrônicos, artefatos variados. Movimentam também um expressivo mercado de artistas e bandas, discursos políticos e conteúdos midiáticos. Circulam também nelas, em última instância, valores de uma esfera nacional e até internacional ${ }^{8}$ (Canclini 2011). Assim é possível apreender parte da dinâmica de desenvolvimento local e regional - e aqui me refiro às disputas pela realidade presente e futura - a partir dessas festas. Marcadamente, essas carregam signos e representações de um mundo rural (Paula 2001), identificados, por exemplo, na indumentária de vários dos artistas que se apresentam, e também nos trajes das pessoas comuns que as frequentam.
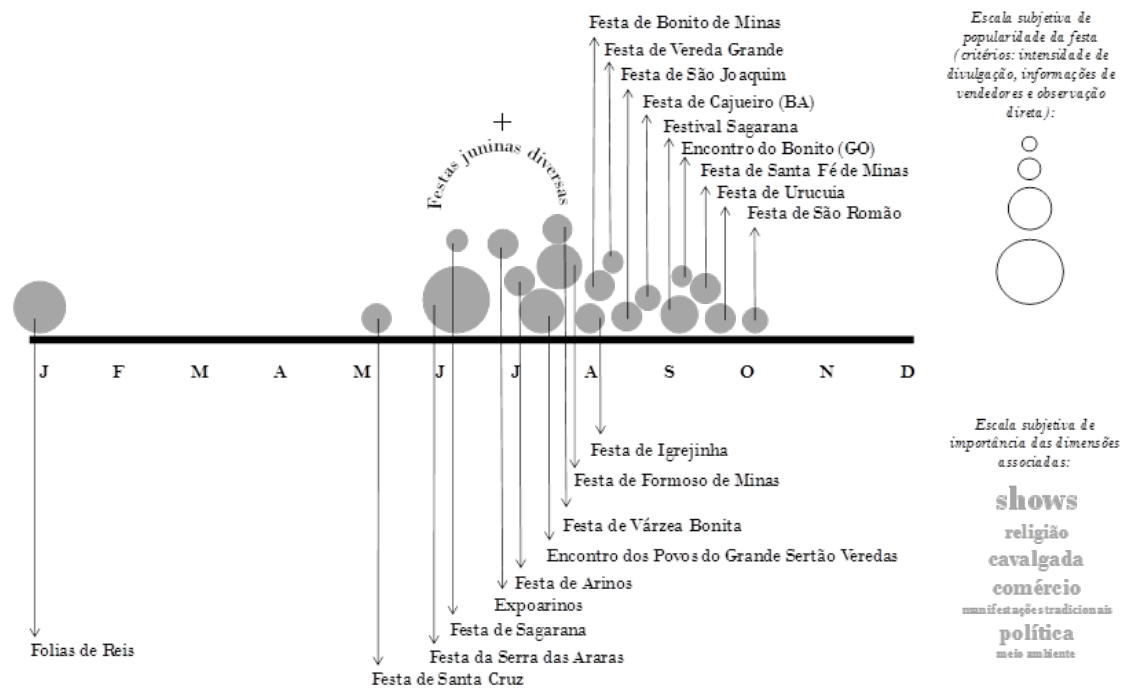

Figura 1 - Representação da dinâmica de festas nas proximidades de Arinos e Chapada Gaúcha, Minas Gerais, 2013. Fonte: o autor 
Tidas essas características gerais, uma das formas de se apreender o circuito de festas é a partir de sua correlação com as folias de Reis, também representadas na Figura 1. Sendo estas festividades tradicionais distribuídas por todo o país, as Folias no sertão mineiro são marcantes e sempre citadas quando do encontro entre residentes locais e visitantes 'de fora'. Mais recentemente, elas movimentam um expressivo número de ex-residentes da região ${ }^{9}$, que, em sua época, aparecem para festejála. Os giros de folias correspondem à realização de jornadas festivas inscritas em um dado território (uma comunidade, um bairro, uma cidade) e configuram o período de ocorrência da folia nos respectivos locais. Cada giro pode durar muitos dias em trânsito por diversos espaços, como casas, igrejas e cemitérios. No sertão mineiro, os giros ocorrem em geral entre 26 de dezembro e 06 de janeiro de cada ano. Sob outro ângulo, as folias constituem rituais de trocas simbólicas que remontam espaços camponeses (Brandão 1981; Pereira 2009). Conformam uma dinâmica marcada pela reunião de pessoas em casas de parentes e vizinhos e pelo deslocamento em diferentes espaços, ao passo que podem ser vistas como sequências de movimentos de expansão e contração com significação profunda na esfera social local (Pereira 2009).

"A extrema concentração e o evidente espraiamento dos festejos religiosos são responsáveis pela circulação, obtenção, acumulação e distribuição das pessoas e de diversos bens e serviços, contribuindo para estabelecer mediações entre inúmeros domínios do mundo social e cosmológico" (Péreira 2009:15).

Subjacente às folias, há expressões de valores e práticas vinculadas à reciprocidade, à unidade social e à identidade local. Tratam-se, então, de dinâmicas nas quais se podem observar sequências obrigatórias de dar, receber e retribuir. Nestas, podem ser notados diferentes tempos, que fazem intercalar o profano e o sagrado, com a particularidade de que é possível imaginálas "como autênticas festas em movimento" (Pereira 2009:26) - os fiéis vão às festas, mas as "festas também vão" às casas dos fiéis. Podem ser pensadas também em termos de instauração de "um tempo de paz e fartura entre os homens" (Pereira 2009:28), 
bem como constituindo episódios para a manutenção de determinadas rivalidades e reputações entre as pessoas.

Quando se transpõem as características apontadas por Pereira ao circuito regional de festas, é possível explicitar um encaixe contundente. $O$ circuito de festas seria a realização temporal e espacialmente amplificada da época das folias, ou mesmo dos giros. Ele movimenta um contingente expressivo de pessoas 'de fora', em uma jornada festiva inscrita em um território que é percorrido de modo a passar por
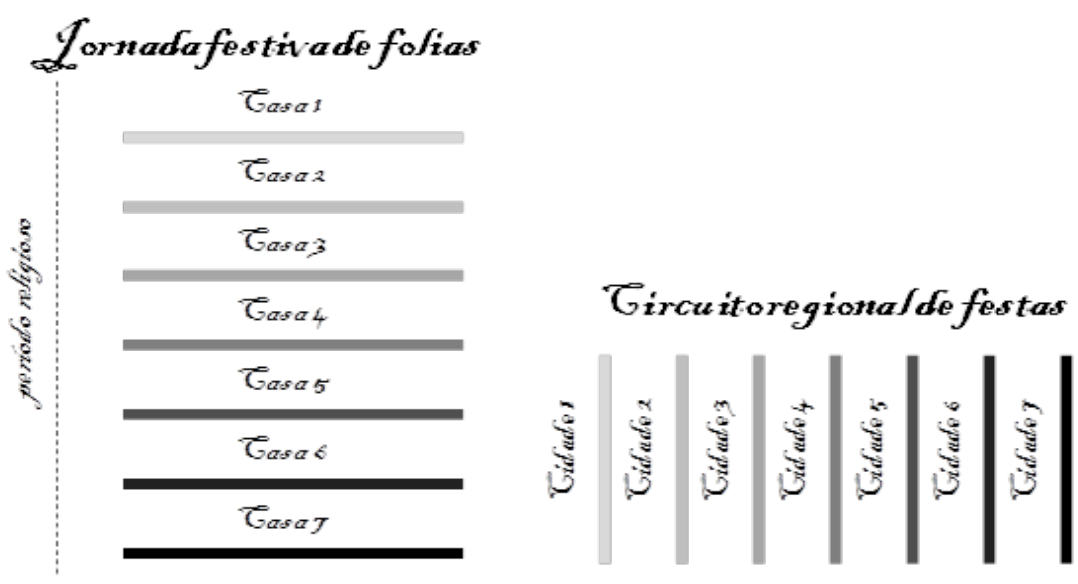

fius. - out.

Figura 2 - Representação de 'movimento' nas Folias e no circuito regional de festas. Fonte: o autor.

espaços diversificados. Inscreve-se igualmente no esquema de expansão e contração - agora, os cavalos, que conduzem os moradores por entre as casas, são carros e motos, e as trilhas são estradas - e de reciprocidade, haja vista a especialidade dos residentes locais em receber e hospedar parentes e amigos. Evidencia-se, similarmente, o hábito lo- 
cal de ficar hospedado - ou de hospedar - de 'pedir pouso na casa de parentes', amigos ou conhecidos. Mesmo porque, inexiste uma rede formal de hospedagem suficiente para instalar o contingente de pessoas que se movimenta na dinâmica associada ao circuito regional de festas, apesar de que o aluguel de casas na 'festa da Serra' é usual, dada sua magnitude. Considerando essas similaridades, uma analogia entre as folias e o circuito regional de festas está representada na Figura 2.

Pode-se observar ressonância em termos de construção identitária e de intercalação de espaços e tempos tidos como sagrados e profanos. Uma única festa pode ser dividida segundo esse critério, e o próprio circuito em si também; assim como os episódios de folias são inaugurados pelo sagrado (Pereira 2009), o circuito tem sido iniciado, grosso modo, pela 'festa da Serra', a maior de todas e cujo conteúdo sagrado em termos de tempo, espaço e intensidade é prático e discursivamente mais significativo que o das demais festas. Se as folias constituem representação da fartura, a época de início do circuito também, porque coincide com o final das colheitas modernizadas de hoje: paz no trabalho. $\mathrm{O}$ circuito regional de festas, em paralelo às folias, parece emergir como representação social do 'movimento'.

Para Cerqueira "o movimento surge como via narrativa de um povo integrado no próprio deslocar-se. Se uma terra onde a mobilidade - no espaço ou no tempo; interna ou externa; física ou existencial - dá forma e sentido ao 'povo dos Buracos"' $(2010: 44)^{10}$, a categoria é acessada para além desse espaço. Assim que movimento é forma de viver (Pereira 2009; Andriolli 2011; Dainese 2016), é cultura, calcada em modos gerados em íntima relação com a natureza. Para Andriolli (2011), 'movimento', 'fartura' e 'liberdade' são categorias nativas acionadas ali em conjunto, que mantêm interdependência entre si e que remetem à ética camponesa. Então, uma ética que marca a região ${ }^{11}$ ainda hoje, apesar de que com diferentes expressões e repertório sígnico modificado. Movimento é acionado quando da constante transposição de terras amplas, é forma de mapeamento alheio e de constituir família, de interconhecimento expresso em forma de conhecer o 
mundo (Cerqueira 2010); trata-se de um produto social da interação complexa entre indivíduos ${ }^{12}$, classes, natureza e cultura.

É assim que movimento enquanto imperativo cultural aparece no plano regional das festas e nas folias. Festas cujo entrelaçamento com a religiosidade e com a política liga atores particulares e cuja dinâmica manifesta parâmetros próprios, socialmente elaborados. Movimento, então, aparece marcando - ou, de certa forma, ligando - festas, folias e política, entre outros. Se em 2013 eu me interessava em apreender as operações das festas em termos de desenvolvimento, percebia, lentamente, não apenas seu entrelaçamento com as arenas da política, mas igualmente a relevância do movimento como marca dessa política; marca que, consequentemente, não poderia ser ignorada para apreensão de quaisquer operações de desenvolvimento. É nas festas, ou também nelas, que política é exercida em interação com 'o povo', acionando uma gama de signos e significados partilhados. A política, os passos e descompassos dos embates de desenvolvimento e o campo artístico-cultural se coadunam ali e se apresentam moldados por cultura.

\section{'Festas da política' ${ }^{13}$}

De um modo geral, as festas do circuito regional podem ser apreendidas a partir de seu conteúdo eminentemente político. Elas são constituídas enquanto fatos políticos por excelência, porque demonstram um caráter instrumental à conquista e reprodução do poder municipal. Delas valem-se os prefeitos e seus concorrentes, entre outros políticos, que as posicionam enquanto eventos de autopromoção e provimento, em uma espécie de discurso político nem sempre com palavras. Tais feitos atravessam um complexo sistema de significação, conforme analisou Chaves em relação às festas de Buritis, município vizinho a Arinos: elas conformam "um discurso estruturado através da articulação coerente de imagens" (2003:102).

Retomo aqui alguns aspectos problematizados por Chaves, dada a correspondência destes com as festas observadas por mim em Ari- 
nos e Chapada Gaúcha. Para ela, as festas não podem ser tomadas como 'meras festas', mas constituem locais exclusivos para a dramatização de determinadas representações. Uma delas, emblemática, faz referência ao fazendeiro, provedor maior, que oferece festas e favores aos 'agregados' ${ }^{14}$, também para tê-los ao seu controle estável. Apesar das transformações recentes e da falência da 'época das fazendas' ${ }^{15}$, a figura do antigo fazendeiro aparece, para Chaves, sendo atualizada no prefeito 'boa gente', de modo que as festas conformam eventos particulares para este reviver. Se o fazendeiro é hoje também representado pelo prefeito, este último realiza favores diversos à população, aos 'agregados'; encerra por provê-los, em troca do endividamento moral destes beneficiários. As festas aparecem, então, como espaços onde esse provimento adquire um status coletivo, partilhado, que, em ocorrendo conforme expectativas previamente construídas, têm o poder de fazer transparecer o bom funcionamento das coisas. Apesar de Chaves endereçar a análise a Buritis, poderia se estar narrando a vida social em Arinos ou Chapada Gaúcha e, provavelmente, em um território um tanto mais amplo ao seu entorno.

"Após a hegemonia do domínio familiar e da fidelidade tradicional que lhe servia de esteio, a relação política passou a inscrever-se num novo contexto social e econômico que no entanto manteve a marginalização de uma parcela significativa da população, os antigos moradores, expulsos das fazendas. Sem a intermediação do patrão, mas mantidas as condições de dependência, a relação direta político-eleitor reforçou o nexo valorativo da pessoa assim como a assimetria na relação, revigorando as características do personalismo na política: hierarquia e paternalismo. Mas, alimentada pela idéia de desenvolvimento, surgiu um segundo eixo valorativo dado pela contraface do político como 'boa pessoa', o 'bom administrador" (Chaves 2003:87).

A festa ali configura, para Chaves, um espaço de diálogo entre a população e os políticos; uma população muitas vezes anônima que, na interação proporcionada, sai do anonimato. Ela constitui evento em que ocorre uma espécie de distribuição persuasiva do poder, exercida pela dissolução momentânea e aparente das assimetrias es- 
tabelecidas no âmbito municipal; talvez com a possibilidade dessa população protagonizar, de modo efêmero, o drama encenado no município, e sentir-se um tanto mais poderosa, um tanto mais pertencida (Chaves 2003:88). Expressam-se nelas a fusão e a multiplicidade de representações. As diversas citações estéticas em Buritis parecem ativar, sobretudo, os signos da modernidade, a partir - e para além da representação de um "domínio moral partilhado" ou do exercício de "uma narrativa construída por processo de justaposição" (Chaves 2003:93-94). É representado "um rito unificador, soldando grupos sociais", incluindo migrantes do Sul, "em uma unidade moral englobante, o município” (Chaves 2003:98), algo análogo ao que podia ser observado na 'festa da Serra' em 2013, no município de Chapada Gaúcha. É nesse contexto que Chaves evidencia a operação de uma linguagem da modernidade nas festas da região, manejada para dramatizar a história do lugar. Projeta-se, contudo, e em paralelo ao "desejo de ser moderno e ao afã do desenvolvimento, a consciência do atraso" (Chaves 2003:96). O senso desta dualidade é representado dramaticamente em Buritis, comunicando uma ideia de desenvolvimento, particularmente, de desenvolvimento econômico.

Vale ressaltar que Chaves se debruçou sobre as 'festas da política', relacionadas ao período antecedente às eleições municipais em Buritis. Sustento, em adição, que o caráter político das festas em Arinos e Chapada Gaúcha é atualizado também ao longo do interstício entre eleições, sugerindo que qualquer tempo é tempo de política ${ }^{16}$ e de reafirmação de valores. $\mathrm{O}$ drama político encenado nas festas apareceu a mim como um continuum. Apesar disso, há que se considerar que o 'tempo da política' manifesta uma dinâmica própria marcada pelas campanhas eleitorais propriamente ditas, algo que nos leva a diferenciar a política que se faz no 'tempo da política' (Palmeira 2001; Palmeira \& Heredia 1995) e aquela que se revela nas 'festas das cidades', ou seja, cada uma parece ter seu movimento próprio, ainda que se possam vislumbrar continuidades. De qualquer forma, a trama da política, assim como a ideia de movimento, auxilia a perceber 'onde de- 
param' elementos variados que entram em cena quando atores sociais contestatórios conformam arenas de disputas envolvendo as festas em Arinos e Chapada Gaúcha. As políticas públicas culturais, que soam ali como contingências, compõem esses elementos e sua incidência será analisada mais adiante.

É possível identificar na 'festa da Serra' - algo observável para outras festas na região - a ocorrência de discursos políticos explícitos, fato que acresce à perspectiva de Chaves. Em 2013, foi feita uma extensa abertura dessa festa por parte do prefeito de Chapada Gaúcha em companhia de outros prefeitos da região. Creio que a fala, realizada entre shows, tenha durado mais de uma hora. Soltavam-se muitos fogos de artifício e evidenciavam-se as façanhas da prefeitura, numa espécie de balanço de gestão. Para além das falas, o efeito simbólico da abertura oficial era marcante, emanado mensagens de provimento e fartura. Desta feita, a 'festa da Serra' parece estabelecer uma analogia ao contexto de Chaves, quando é possível vislumbrar ali uma variedade de signos estéticos, dentre os quais figuram aqueles advindos da cultura country (cowboy), da estética 'gaúcha' manifesta em trajes de dança, do modo 'sertanejo', entre outros. Trata-se de um momento de ratificação de alianças, onde são apresentadas danças tradicionais gaúchas, ao passo que os 'gaúchos' são posicionados enquanto ícones do desenvolvimento hegemônico em curso. A relação festa-política no território guarda consigo um significado polissêmico onde um dos significados constituise enquanto manifesto de adesão à modernidade, sendo esta também representada pela cultura de massas. Constituindo espaços também para a valorização discursiva da 'tradição', as festas do circuito regional de festas não raro expõem oposições entre o tradicional e o moderno; se não na mesma festa, em ocasiões complementares, a exemplo da exposição agropecuária de Arinos (Expoarinos) e da festa comemorativa de seu aniversário (Festa de Arinos). Em última instância, as festas do circuito regional parecem encerrar um 'território de festas'.

Tal qual observado em Buritis, ideias de desenvolvimento são projetadas no circuito regional de festas, acionando moldes onde são 
talhadas identidades coletivas e, assim, construídos espaços públicos. Trata-se de um tempo-espaço em que são elaborados significados para a constituição da realidade - em último caso, um exercício de representação social dessa realidade - mediados pela oferenda e pela gratuidade $^{17}$. Se nas festas do 'tempo da política' o desenvolvimento econômico aparece não sendo objeto de disputa, mas de consenso, é nesse sentido que é forjada a particularidade de algumas das festas do circuito regional de festas, porque atores sociais nele inseridos ligados enquanto uma rede contestatória - posicionam o desenvolvimento como objeto de disputa, a exemplo do Encontro dos Povos, do Festival Sagarana e do Encontro do Bonito (GO). Estas três festas, em particular, constituem importantes espaços de ação dos atores contestatórios, que mobilizam valores de conservação ambiental, de manutenção dos povos e comunidades chamados de 'tradicionais do Cerrado', promovem fóruns de debate para problematizações de questões nomeadas 'de desenvolvimento', tais quais: os efeitos da construção de pequenas centrais hidroelétricas em rios da região; aspectos das políticas culturais nos planos municipal, estadual e federal; a implantação de novas unidades de conservação; as consequências da extração do gás de xisto na região; a articulação entre movimentos sociais. Entre outras ações, promovem também apresentações de grupos de crianças, jovens e adultos, que são estimulados a ensaiar ao logo do ano. E, de modo marcante, forjam alianças particulares calcadas na construção de afinidades e de afetividades (Meyer 2019).

Em paralelo às mensagens de desenvolvimento dueladas no interior do circuito regional de festas, destas depreende-se um forte sentido amenizador de cotidianos, particularmente o da 'roça' e o das pequenas sedes municipais masculinizadas ${ }^{18}$, onde as possibilidades matrimoniais ficam reduzidas. Assim, as festas devem ser contextualizadas em Arinos e Chapada Gaúcha como espaços socialmente construídos para proporcionarem o início de relacionamentos amo$\operatorname{rosos}^{19}$. Evidencia-se, daí, o valor da festa enquanto espaço para lidar com regramentos morais sexualmente repressores, particularmente às 
mulheres, ressignificados em termos de tempo de amenizar ansiedades em um ambiente masculinizado. Em 2013, a 'festa da Serra', por exemplo, era associada por jovens de Chapada Gaúcha a: 'palco com shows, muita cerveja, promessa de pegação’ e, inclusive, prostituição. Apresentava-se como espaço privilegiado para se beijar. Como diz um ditado local, "boca que não beija, pinga nela" (sic). Elas constituem, enfim, espaços importantes de reprodução social num contexto onde os encontros para paqueras podem ser esparsos no espaço e no tempo. Movimentam aspectos importantes da vida, como o sexo, a compra e venda de produtos - e as rendas geradas nessas transações adquirem significância material -, relações de interconhecimento - reforçando e ampliando laços e a dimensão da família - as solidariedades - a partir dos trânsitos de ir e vir das festas e dos ritos de hospitalidade relacionados aos atos de hospedar ou de ser hospedado - e a euforia em sentido próximo a uma espécie de 'descontrole', quando "o ânimo torna a convivência apreciada, ele também pode conduzir aos rumos de uma aceleração que beira o 'descontrole'” (Dainese 2016:658).

Em um território personalista fundado na figura do 'fazendeiro'-'patrão', os provimentos proporcionados pelos prefeitos são operados em um circuito regional de festas e podem ser qualificados em termos de 'movimento' e de espaços particulares: afetivo-amorosos; espirituais; de euforia; de se fazer compras múltiplas; de se vender e ganhar dinheiro; de sociabilidade em um sentido amplo etc. Estes invadem esferas diversas da vida cotidiana, econômica, afetiva, social e religiosa. A divisão em espaços relativamente 'profanos' e 'sagrados', tal como se pode observar nas folias, parece conciliar essas múltiplas esferas e sociabilidades. No caso do circuito regional de festas, uma das particularidades é de cenário, que guarda a proximidade e a interação entre o prefeito e a população. Na perspectiva de Chaves, "a hierarquização faz-se por meio mesmo da negação da distância social: o político se credencia como mediador pela encenação de familiaridade e intimidade com as demais pessoas" (2003:107). Para alguns na 'festa da Serra' à época, o ideal seria que o prefeito dançasse tão bem 
quanto aquele que o antecedeu, algo que reafirma a expectativa desta interação e proximidade.

Destaca-se do circuito regional de festas a forte vinculação com a política e com a reprodução do controle de poder local, principalmente. Mas as festas, sendo expressão de 'movimento' e personalismo - qualificados em termos de provimentos particulares -, parecem inscrevê-los no circuito enquanto imperativos culturais. Estes encerram por imprimir marcas àquelas arenas que eu tanto perseguia, em que se disputam rumos de desenvolvimento em torno da 'área da cultura'. Estando o personalismo em jogo, entretanto, não se pode perder de vista a relação com o esquema faccional de controle do poder (Palmeira \& Barreira 2006).

\section{Ritornello da euforia: as prefeituras e a 'área da cultura'}

Se imperativos culturais metaforicamente constituem a marca interpretativa encenada por atores sociais, imperativos 'fluidos' elementos de caráter efêmero-conjuntural, como as novas políticas e ações artístico-culturais que incidem no plano local - podem ser vistos como uma espécie de roteiro; o jugo a que os atores locais devem se submeter; estes soam como contingências que imprimem no jogo novas marcas. Os imperativos culturais parecem estar para os alargamentos temporais - o tempo 'faz cultura' - e para a identidade local assim como imperativos fluidos parecem estar para os alargamentos espaciais - as políticas 'fazem espaço' - e para a construção da identidade institucionalizada - a exemplo da nacional - ou a integração política. Em Arinos e Chapada Gaúcha, interessei-me em esboçar como tais contingências seriam operadas na trama do desenvolvimento e de que forma estas interagiriam com modos ali já mais sedimentados. De que forma estas primeiras operariam na constituição de uma 'realidade artístico-cultural' local? Ou, antes, qual seria o conjunto de ações e políticas que caracterizariam essa realidade?

Para além das festas, investiguei a ocorrência de ações artístico-culturais e também a forma como agentes locais processavam eventuais 
políticas culturais em Arinos e Chapada Gaúcha. Na sede municipal de Arinos algumas atividades principais compunham uma espécie de 'cotidiano artístico-cultural' à época de 2013-2014: aulas de música na Secretaria Municipal de Cultura (SMC); atividades de dança realizadas no âmbito de um programa municipal chamado Idade de Ouro; ações de um Ponto de Cultura ${ }^{20}$. Em termos de políticas públicas culturais que incidiam, ou seja, aquelas formuladas um tanto mais fora dali, havia o Ponto de Cultura, conduzido por uma organização da sociedade civil, e o Sistema Municipal de Patrimônio Cultural (SMPC), operado majoritariamente pela prefeitura. Em Chapada Gaúcha era possível observar, de modo marcante: atividades de artesanato junto ao Centro de Referência em Assistência Social (CRAS); danças tradicionais gaúchas praticadas do Centro de Tradição Gaúcha, ações de um Ponto de Cultura. Em relação às políticas públicas culturais 'externas', Chapada Gaúcha, tal qual Arinos, revelava o Ponto de Cultura, também operado por uma organização da sociedade civil, e o SMPC pela prefeitura.

Em boa medida as SMCs em Arinos e Chapada Gaúcha ${ }^{21}$ foram criadas como resposta a estímulos emanados quando da operação de políticas públicas culturais nos planos estadual e federal. Por essa razão, e também considerando que a incidência dessas políticas ali é relativamente recente, trata-se de secretarias cujas figuras estão em institucionalização. Apesar das políticas adentrarem a 'área da cultura' e a própria 'área da política', diferente das festas, elas aparecem como novos dispositivos, passíveis de serem manejados pelos atores sociais em cena; por terem o potencial, então, de desestabilizar o status quo, encerram mesmo por concorrer com festas cuja dinâmica já é conhecida.

\section{. Abrem-se parênteses para alguns dados...}

Em termos de investimentos em arte e cultura, Chapada Gaúcha e Arinos não estão fora daquilo que é usual nos municípios brasileiros com menos de 20.000 habitantes (IBGE 2007). Em 2013, seus prefeitos destinavam aproximadamente $1,3 \%$ do orçamento das prefeituras 
para operar a 'área da cultura'. Ressalta-se, entretanto, que desde aproximadamente o ano 2000, esse percentual vinha sendo acrescido com recursos angariados a partir de um mecanismo que permitia reverter parte do 'Imposto sobre Circulação de Mercadorias e Prestação de Serviços' à preservação do Patrimônio Cultural (ICMS-PC).

Sendo a 'área da cultura' em Arinos e Chapada Gaúcha marginal em termos de investimentos, as festas ocupam parcela expressiva dos recursos destinados a ela. O mecanismo do ICMS-PC, ou melhor, a Política Estadual de Patrimônio Cultural de Minas Gerais (PEPAC-MG) aparece sendo, na prática, a única política pública cultural acessada pelas prefeituras - evidentemente que a prefeitura formula também sua própria política cultural, em termos de festas. $\mathrm{O}$ mecanismo do ICMS-PC pode ser tomado como imperativo fluido a partir do qual as prefeituras forjam novos dispositivos de obtenção de recursos, 'para a preservação do patrimônio cultural'. Alcançar o status de apta à utilização desses recursos, entretanto, não constitui tarefa fácil, pois demanda o direcionamento de esforços significativos, quando não a destinação de um funcionário exclusivo da prefeitura para lidar com as burocracias intrínsecas ao ICMS-PC. Assim, faz-se necessária uma breve explanação a respeito dos meandros burocráticos associados a esse mecanismo. Ou seja, trata-se de evidenciar o que as prefeituras fazem com o 'novo' ICMS-PC ali.

A utilização desses recursos em Minas Gerais está prevista na Lei 13.803, que dispõe sobre a "distribuição da parcela da receita do produto da arrecadação do ICMS pertencente aos municípios" (Minas Gerais 2000). Tal Lei, fundada na Constituição Federal, determina que $75 \%$ do valor arrecadado pelo ICMS devem ser repassados aos municípios, de acordo com o volume de arrecadação, ao passo que os restantes $25 \%$ devem ser repassados conforme regulamentação dada por lei estadual específica, no caso a Lei 13.803. A lei mineira coloca o patrimônio cultural como rubrica para este último repasse. Assim, uma das formas de as prefeituras reaverem a parte que lhes corresponde da arrecadação do ICMS é constituindo 
o que se chama localmente de SMPC. Para instituí-lo, é requisito que as prefeituras sigam regulamentação específica do Instituto Estadual do Patrimônio Histórico e Artístico de Minas Gerais (IEPHA). Este então condiciona às prefeituras que: a) promulguem legislação municipal específica acerca da utilização do patrimônio cultural local; b) instituam um Conselho Municipal de Patrimônio Cultural (COMPAC); c) elaborem um plano municipal de patrimônio cultural; d) constituam um órgão ou setor específico para a gestão do patrimônio cultural no município, a exemplo das SMC, e; e) constituam um Fundo Municipal de Patrimônio Cultural (FUMPAC). Uma vez cumpridas essas difíceis tarefas burocrática e instituídos os SMPCs, as prefeituras passam a 'pontuar' junto ao ICMS-PC; pontuação esta que, mediada pelo IEPHA e suas regulamentações, irá determinar o montante de recursos financeiros a serem transferidos aos municípios a partir da 'rubrica do patrimônio cultural'.

Os recursos conquistados a partir das pontuações junto ao ICMS -PC são repassados às prefeituras e estas ficam obrigadas a repassá-los aos FUMPACs. Uma vez estando nesse fundo, os municípios somente podem utilizá-los sob o crivo dos COMPACs que, por sua vez, são compostos envolvendo obrigatoriamente organizações da sociedade civil local. A orientação do IEPHA é a de que "o ideal é que se faça a composição do órgão colegiado de forma paritária ou por maioria da sociedade civil organizada, a fim de garantir a máxima participação da comunidade nas decisões" (IEPHA/MPMG 2011:24). Por meio de reuniões deliberativas, os COMPACs ficam encarregados da elaboração do planejamento e o ordenamento de gastos dos recursos do ICMS-PC transferidos do Estado de Minas Gerais, a partir de uma diretriz de 'gestão democrática e compartilhada' com a sociedade civil. Importante destacar, nesse sentido, que as prefeituras ficam obrigadas a repassar somente 50\% dos recursos obtidos pelo ICMS-PC aos FUMPACs (IEPHA/MPMG 2011:16), de modo que os outros 50\% podem ser utilizados conforme convir à prefeitura (ver Figura 1), 'desde que seja com cultura', na 'área da cultura'. 
Meyer: Onde Depara o Novo?

\section{.... e fecham-se parênteses}

É significativo que as duas principais organizações da sociedade civil da 'área da cultura' de Arinos e Chapada Gaúcha - e, pode-se dizer, não havia outras cuja existência ultrapassasse o nível jurídicoformal - não fossem convidadas a compor os COMPACs. Essas organizações eram as que, inclusive, geriam os Pontos de Cultura em seus respectivos municípios. Observava-se aí um importante ponto de subversão da lógica 'proposta' pelo governo estadual. Localmente, passa a ser menos incômodo aderir, por exemplo, aos estranhos programas de educação patrimonial ${ }^{22}$ sugeridos pelo IEPHA, que envolver organizações locais no processo de gestão do patrimônio cultural, enfim, da 'área da cultura'. Friso então o indício de que as ações de determinadas organizações locais, particularmente aquelas da sociedade civil, articuladas ou ligadas segundo um viés contestatório, são percebidas como ameaça por outro grupo de atores, ou seja, pelas prefeituras. Essas ações, portanto, adentram o esquema faccional de controle do poder local e nas sanções derivadas desse modelo (Palmeira 2006).

Há um problema muito grande com a troca de gestor [o prefeito] [...] e o Conselho fica meio com a cara do gestor [...]. Seria muito melhor se o presidente do Conselho fosse externo à gestão [...]. O Sistema [Municipal de Patrimônio Cultural] mesmo começou a ser articulado em 2009, com a criação da Lei do Fundo. O prefeito usava [como bem quisesse] o recurso do ICMS Cultural. Em 2010, já devia ser obrigatório o uso específico dos recursos [...]. O dinheiro era usado para pagar as bandas [das festas] de Serra das Araras. (Fala de uma funcionária da Prefeitura de Chapada Gaúcha).

A adesão ao mecanismo do ICMS-PC parece constituir um mecanismo politizante no âmbito da administração municipal, porque submete a utilização de recursos da 'área da cultura' às deliberações do COMPAC. Dada a obrigatoriedade de compô-lo com a sociedade civil atuantes no município, há, entretanto, o desinteresse dos prefeitos em transferir a totalidade dos recursos aos FUMPACs, a despeito da gestão compartilhada. Encerram por transferir apenas 50\%, igualmente em regime de obrigatoriedade. Com os 'outros 50\%', então, abre-se 
um importante espaço de manobra à prefeitura, brecha por sua vez formulada no âmbito da PEPAC-MG e criada para garantir a adesão dos municípios ao aparato burocrático do ICMS-PC. Contudo, ressalto que até o ano de 2010 os recursos angariados a partir desse mecanismo eram utilizados quase que livremente pelos prefeitos (ou seja, 100\% dos recursos, ao invés de 50\%). Mas as amarras parecem ter sido apertadas à medida que aumentou o grau de institucionalização da política, de modo que não seria estranho, em um futuro próximo, o lançamento de uma normativa do IEPHA determinando o aumento dos percentuais a serem transferido aos FUMPACs. A margem de manobra das prefeituras, por outro lado, não encerra nessa artimanha dos $50 \%$, conforme poderá ser percebido mais adiante.

Aspecto importante para entender a trama dos atores sociais na 'área da cultura' diz respeito àquilo que se entende por patrimônio material. Ainda que este termo designe algo bem abrangente, a essência do instrumento do ICMS-PC está assentada na preservação dos componentes materiais do patrimônio ${ }^{23}$. Por conta do desdobramento particular da história do Brasil, Minas Gerais lista-se como o Estado que abriga a maior quantidade de prédios históricos no país. É neste sentido que pode ser observada certa indução à centralidade das ações do ICMS-PC em torno do inventário de obras, prédios e artefatos históricos, assim como do tombamento e da restauração. Em outras palavras, os recursos financeiros alocados à política aparecem condicionados ou subordinados à visão cristalizada em monumentos. Ocorre que o sertão mineiro, a despeito da coerência espacial do ICMS-PC, abriga contexto onde outras dimensões artístico-culturais são consideradas mais expressivas que a do patrimônio material; pela simples ausência relativa de prédios históricos.

Existem, então, implicações significativas em termo de mensagem simbólica emanada do Estado aos locais. De certa forma, o reflexo da sobrevalorização da dimensão material do patrimônio corresponde à instituição de uma espécie de 'ditadura da cultura' quando a PEPAC-MG encerra por querer determinar, em certa medida, a rea- 
lidade artístico-cultural desses municípios. Acresce-se a isto o fato de os prefeitos terem que destinar esforços e recursos consideráveis para gerir os SMPCs (alocar funcionários, gerir um conselho, ter um setor específico, produzir relatórios detalhados, organizar oficinas etc.) para continuar pontuando junto ao ICMS-PC.

Os valores subjacentes à propagação da PEPAC-MG, 'negociados' ao nível municipal, contrastam com os valores nativos detrás do modus operandi das prefeituras, pressionando a racionalidade local e suas concepções de tempo e espaço. Trata-se de racionalidade intrincada aos poucos na prefeitura, que carregando padrões de inevitabilidade e de linguagem para o financiamento do estado ao município, como que querendo padronizar o múltiplo, aplainar os tempos e incidir nas formas nativas de distribuição de poder. Assim, a imposição de complexo aparato burocrático - e financeiro, porque as prefeituras têm também que instituir as SMC - e a centralidade da dimensão material no âmbito das questões patrimoniais demonstram que a adesão ao ICMS-PC por parte das prefeituras, por um lado, se mostra análoga à realização de uma vontade direcionada a outrem, em conteúdo (o patrimônio material) e em forma (o SMPC), em termos aproximados às reflexões de Escobar (1998) e Ribeiro (2008). A política de patrimônio cultural é revelada como estrutura de desenvolvimento (Arce 2003), que chega pronta, completa, apesar das brechas e da necessária instituição dos conselhos locais, que surgem já amalgamados à dimensão material. Em certa medida, o ICMS-PC pode ser tomado como uma força colonizadora (Escobar 1995) e despolitizante (Fairhead 2000). Uma das facetas da despolitização é bem conhecida como a expansão e o enraizamento do poder burocrático do Estado, concomitantes à projeção de representação particular da vida econômica e social, inibindo determinadas práticas políticas locais.

Em contraponto, uma vez havendo a indução do estado e a adesão dos municípios para a montagem de complexos SMPCs, com conselho, fundo, lei, plano, setor específico etc., os prefeitos não hesitam em subvertê-los o quanto podem, exatamente no sentido de 
fazer reproduzir o já estabelecido esquema de controle do poder local, assentado na autopromoção e no agrado ao 'povo' para, finalmente, a conquista de votos. Se há margem de manobra para a prefeitura manejar recursos do ICMS-PC por meio da não destinação ao FUMPAC (os '50\%'), é possível, também, subverter aqueles que são a este destinados, em um esquema em que se aceita certa imposição do Estado de Minas Gerais, mas em que se dá vazão a projetos 'locais', por sua vez formulados quando outras contingências aparecem defronte a administração municipal. No contexto do EPGSV (ver Figura 1) realizado em 2013, um desses projetos - ou 'demandas locais' - parecia ser lidar com determinados atores contestatórios e sua influência sobre diversos grupos em Arinos e Chapada Gaúcha, no sentido de tentar limitar a ação pública dessa rede.

Há que se entender, então, o contexto de uso dos recursos transferidos ao FUMPAC de Chapada Gaúcha no ano de 2013. Eles foram usados pela prefeitura para dar fim a um embate local que sempre aparecia: o conteúdo da 'programação artística' do EPGSV. Enquanto a prefeitura busca por shows localmente mais populares, que carregam consigo elementos de cultura de massas e que estão engajados no esquema das 'festas da política' tratado por Chaves, representantes locais da sociedade civil - organizados enquanto essa rede contestatória de padrões - almejam inserir na programação artistas que, de alguma forma, manejem referências da 'cultura de tradição', das representações da 'roça', tal como aquelas relacionadas às folias de Reis. Conforma ali um terreno de disputas de representações (incluindo as imagens de rural) que acaba por expressar valores, conhecimentos, visões de mundo e realidades distintas. O EPGSV, o Festival Sagarana e o Encontro do Bonito (GO), a despeito de terem sido representados compondo o circuito regional de festas (Figura 1), devem ser tomados como festas internamente diferenciadas. Esses eventos podem ser opostos aos demais pela movimentação de questões de desenvolvimento (ambientais, artístico-culturais, de gestão pública, entre outras), pela realização de 'apresentações artísticas' não convencionais e pela valorização de 
representações da 'cultura de tradição'. A rede de atores contestatórios apresentada logo no início, composta por representantes da sociedade civil ou afiliados, é quem busca imprimir tal orientação no território que inclui e circunda Arinos e Chapada Gaúcha.

Em 2011, uma organização da sociedade civil atuante em Chapada Gaúcha angariou recursos externos para a promoção do EPGSV nos anos de 2012 e 2013. Tal feito garantiu a essa ONG e seus agentes e afiliados locais a prerrogativa de coordenar o evento e, dessa forma, conferir-lhe, convenientemente, determinadas características. Apesar disso, recursos complementares, irremediavelmente, tiveram que ser solicitados ao prefeito desse município para viabilizar a realização do encontro. Em 2013 a prefeitura de Chapada Gaúcha buscou destinar o mínimo possível de recursos ao EPGSV, segundo a justificativa de que a coordenação do evento - vinculada à rede contestatória - já dispunha de montante mais que suficiente a sua realização. Não obstante a real conquista de recursos para a execução de um evento daquela envergadura, a coordenação demonstrava fragilidade, porque, diferente das edições anteriores a 2013, não se podia contar de fato com a capacidade instalada da prefeitura e, assim, com a possibilidade de combinar recursos diversos em situações limites. Se a esta se recorria, ficava-se, concomitantemente, sujeito ao jugo do prefeito. Desta feita, e de modo quase que inevitável, faltaram recursos essenciais para a realização da edição de 2013, ocasião em que a coordenadora do evento encerrou por recorrer à prefeitura.

Não se pode dizer que os recursos foram negados, contudo eles foram cedidos em troca da possibilidade de escolha da programação da noite de sábado - diga-se, a principal - por parte do prefeito de Chapada Gaúcha, a despeito de todo o processo participativo de caracterização do EPGSV que o antecedia. Coincidentemente, tratava-se da mesma noite em que ele faria pronunciamento em palco, como que abrindo o EPGSV, como que querendo remontar a 'festa da Serra'. Assim, a questão da disponibilidade de recursos mostrava-se menor do que o incômodo causado pela alteração do status quo por integran- 
tes de uma rede contestatória que se mostra hábil em tecer alianças múltipla ${ }^{24}$. Em outra perspectiva, está em jogo a ressignificação da 'área da cultura' e seu imbricamento com aquilo que convencionei chamar aqui de imperativos fluidos e culturais.

É significativo que os recursos finalmente aportados pela prefeitura ao XII EPGSV - em troca da escolha da 'programação artística' - tenham sido oriundos do FUMPAC, aqueles mesmos que seriam regrados segundo o IEPHA e alocados a partir do COMPAC ${ }^{25}$. Como resultado, a prefeitura escolheu como show principal da noite de sábado algo que remetesse aos grandes shows, aos 'shows sertanejos', de maior apelo, atendendo aos gostos imediatos da população. Nesta noite, após a apresentação da dupla 'sertaneja' 'Kleuton e Karen', foi oferecido, então, o show do artista 'Cowboy Estradeiro', mais bem satisfazendo os gostos do 'povo', ou melhor, as intenções explicitadas por representantes da prefeitura. A interferência da prefeitura, entretanto, aparece neste caso mais como retaliação simbólica a um conjunto de ações, valores e atitudes que lhes parecia estranho e ameaçador - e aqui se pode citar a altura mais baixa desejada para o palco, a 'programação artística', as alianças tecidas com organizações da sociedade civil e grupos de grandes centros urbanos, entre outras características - que algum esforço exaustivo para configurar a programação a partir de direcionamentos de maior apelo popular.

Se a incidência da PEPAC-MG aparece no território Arinos-Chapada como elemento despolitizante e regrador em termos de racionalidade burocrática, a forma escolhida pelos prefeitos para lidar com a política institucionalizada induzida pelo Estado se mostra única, com contornos bastante particulares em termos de agência, ou seja, de margem de manobra para tocar adiante projetos desejados. $\mathrm{O}$ esquema a seguir (Figura 3), nesse sentido, elucida esta operação. Outro exemplo emblemático desse tipo de manobra corresponde ao tombamento de uma escola em Chapada Gaúcha como patrimônio histórico material. A intenção era viabilizar uma reforma demandada pelos usuários em um prédio relativamente recente e nada diferente dos demais. 


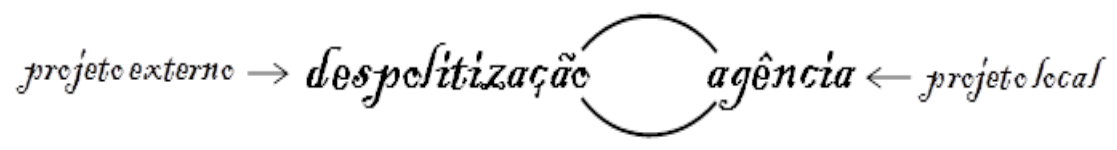

Figura 3 - Representação esquemática da relação despolitização-agência nos municípios de Arinos e Chapada Gaúcha, Minas Gerais. Fonte: o autor.

\section{O igual e o diferente: embates e contestação}

A escassez de recursos destinados à 'área da cultura' aparece naquele território como algo relativo e estreitamente vinculado ao controle do poder local. Havendo a imbricação festas-poder-cultura, os recursos da 'área da cultura' são acessados para a operação de festas de 'agrado ao povo' 26 engajadas no controle personalista do poder, a exemplo da 'festa da Serra'. A 'área da cultura' pode ser posicionada como significante de festas personalistas ligadas por 'movimento', em um circuito regional de festas. Se 'movimento' pode ser tomado como imperativo cultural porque constitui forma intrínseca de conhecer o mundo, personalismo o seria a partir da ressonância profunda - e mesmo pela retroalimentação - entre este tipo de ação e o 'povo'. Isto, por outro lado, não implica ignorar a existência de interesses em jogo e de esforços assimétricos quando a reprodução social do rito 'festa' está em questão.

Torna-se evidente que quaisquer tentativas para ressignificar a 'área da cultura' podem ser tomadas com estranhamentos por parte dos prefeitos, e até como afronta. É também nesse sentido que reside a qualidade da contestação empenhada por parte da rede contestatória. Em 2012, como fruto da ação de representantes dessa rede e de organizações ligadas a ela, foram angariados recursos para a implantação de centros artístico-culturais nas sedes municipais de Arinos e Chapada Gaúcha. Tratava-se dos 'Espaços Mais Cultura' (Vasconcelos $\&$ Santos 2010), ou seja, de infraestruturas ${ }^{27}$ viabilizadas a partir do programa 'Mais Cultura'28, do Ministério da Cultura (MinC). Para 
a viabilização dessas infraestruturas, o MinC aportaria, à época, $\mathrm{R}$ \$ $500.000 /$ centro. A efetivação desses espaços, no entanto, somente seria possível com contrapartida da ordem de R $\$ 100.000 /$ centro por parte das prefeituras. É bastante incomum que cidades do porte de Arinos e Chapada Gaúcha disponham de aparelhos destinados exclusivamente a finalidades artístico-culturais, algo que retrata o contexto de oportunidade ímpar que havia sido instaurado por membros de uma sociedade civil contestatória. Estes espaços de fato não chegaram a ser construídos - em Arinos as obras chegaram ao estágio da terraplanagem, ao passo que em Chapada Gaúcha sequer foram iniciadas - e os recursos foram devolvidos ao MinC, sob a alegação de que a contrapartida seria muito dispendiosa às prefeituras. Alguém poderia inferir que a autoria da construção desses espaços recairia ao prefeito da gestão anterior, haja vista que se tratava de período de transição política entre prefeitos. Entretanto, quando da entrada dos novos prefeitos, as obras não haviam sido iniciadas de fato, de modo que, na prática, as autorias não apareceram publicamente anunciadas, particularmente em Chapada Gaúcha. A evasiva das prefeituras, dessa forma, foi emblemática das prioridades estabelecidas por seus representantes e das oposições conformadas com o ingresso dos novos prefeitos. Nesse sentido, está em jogo aqui a atitude de minar a capacidade de doar do grupo opositor contestatório.

Parece nítido, do ponto de vista das prefeituras, que gastar 100 mil em festas ${ }^{29}$ 'é mais proveitoso' que gastá-los em um 'Espaço Mais Cultura', espaço este que surge estranhamente no seio 'área da cultura'. De modo similar, a inauguração desses espaços valorizaria a articulação política de importantes representantes da rede contestatória e, em última instância, colocaria em evidencia sua ação em sedes municipais onde se retomavam oposições com os novos prefeitos. Entre 2009 e 2012, foram estabelecidas, de um modo geral, alianças brandas entre agentes da rede e prefeitos, tanto em Arinos como em Chapada Gaúcha. Com a transição política para outras facções, anularam-se os acordos tácitos de respeito mútuo e instalaram-se oposições, parti- 
cularmente, no intuito de desconstruir bases sociais conformadas no período antecedente; essas bases, assim, sinalizavam possibilidades de perfurar o esquema faccional de controle de poder ali. Ações diversas forjadas no âmbito da rede contestatória, dentre elas os Pontos de Cultura, causavam estranhamentos. Os Pontos porque eram revelados como espaços artístico-culturais a partir dos quais se visibilizava a interlocução entre o 'povo' e as organizações propositoras desses Pontos. Assim ficava em disputa o significado da 'área da cultura' que participa na reprodução de poderes personalistas. Importante destacar, nesse sentido, que o conjunto de ações da rede em 2013 tomava proporções significativas em termos de construir possibilidades de desestabilização do controle do poder local por parte das prefeituras.

É possível identificar uma espécie de jogo no qual estão envolvidas políticas culturais e ações diversas na 'área da cultura'. Enquanto representantes das prefeituras parecem construir sua margem de manobra a partir de 'festas personalistas' e, na medida do possível, da realocação de recursos do ICMS-PC, atores ligados à rede contestatória parecem valer-se, entre outros elementos, de políticas culturais encarnadas no programa 'Mais Cultura'. Em outra perspectiva, imperativos fluidos aparecem reforçando a operação de imperativos culturais particulares, ao passo que são também manejados para produzir desestabilizações e, assim, para contestar parte destes últimos. Com isso, a natureza da contestação caracteriza-se menos por oposição explicitada à prefeitura e mais pela qualidade das pretensões artístico-culturais assumidas, ou seja, pelos valores que se busca agregar à 'área da cultura'. Então, a capacidade de alguns em subverter - as prefeituras, por exemplo, em relação, ao ICMS-PC - e a habilidade de outros em tecer alianças supralocais e inovar por meio da articulação em rede são mediadas por políticas públicas culturais que, de alguma forma, aparecem favorecendo a redistribuição de poderes e a multiplicidade de organizações atuando na 'área da cultura'. Está aí também representada a heterogeneidade intrínseca ao próprio Estado que, de modo análogo ao território Arinos-Chapada, abarca disputa pela realidade artístico-cultural. 
Para além da adesão a determinadas políticas culturais, as ações de atores contestatórios acabam estando direcionadas ao circuito regional de festas. Se pela natureza de suas festas o circuito carrega signos do personalismo e da massificação de valores de uma macro ordem (Canclini 2011), ao mesmo tempo ele é invadido por eventos político-culturais ligados à rede contestatória, que exacerbam a 'cultura de tradição'; apesar da intensidade ainda em expansão, tais eventos encerram por diversificar as mensagens emanadas e por ressignificar o próprio circuito, com limitações. Ainda que o EPGSV, o Festival Sagarana e o Encontro do Bonito (GO) possam ser vistos compondo o circuito regional de festas, estes inscrevem o território Arinos-Chapada em um 'circuito alternativo de festas', tal qual está elucidado na Figura 4. Tal inscrição é desenhada a partir de alianças diversas tecidas entre representantes de cada uma das festas desse circuito alternativo - a maioria também ligada à política de Pontos de Cultura - e atores da rede contestatória em Arinos e Chapada Gaúcha. Desse ângulo, a própria rede pode ser visualizada como sendo muito mais ampla, e operando a partir de mecanismos particulares de construção de afinidades, afetividades, alianças (Meyer 2019) e solidariedades. Analogamente, essa rede mais abrangente aparece como resultante e resultado das políticas públicas culturais de caráter popularizante, a exemplo do programa 'Mais Cultura'. Em últimas palavras, essas políticas parecem proporcionar uma espécie de disposição contestatória ligante, operando como potente instrumento de mudança social. Daí que algumas políticas públicas a exemplo da de Pontos de Cultura -, ainda que sejam ofertadas nos âmbitos estadual e federal, não são exatamente 'externas'.

Esse contraponto - indiretamente relacionado ao modo personalista de fazer política - que se configura é relevante para dar coerência à relação que busco salientar entre 'área da cultura', desenvolvimento, política e ação de atores sociais. Se, por meio da primeira apreendem-se imperativos culturais que fundamentam dinâmicas de desenvolvimento materializadas nas festas, nesse campo, coincidentemente, ficam visiveis os embates e a trama estabelecida entre atores sociais na tentativa de validação de diferentes visões de mundo. As políticas cul- 
turais popularizantes, a inserção contestatória no circuito regional de festas e a projeção de um circuito alternativo de festas lançam novas cores ao horizonte. Sobretudo porque as festas ali são rituais de trocas simbólicas importantes na vida social.
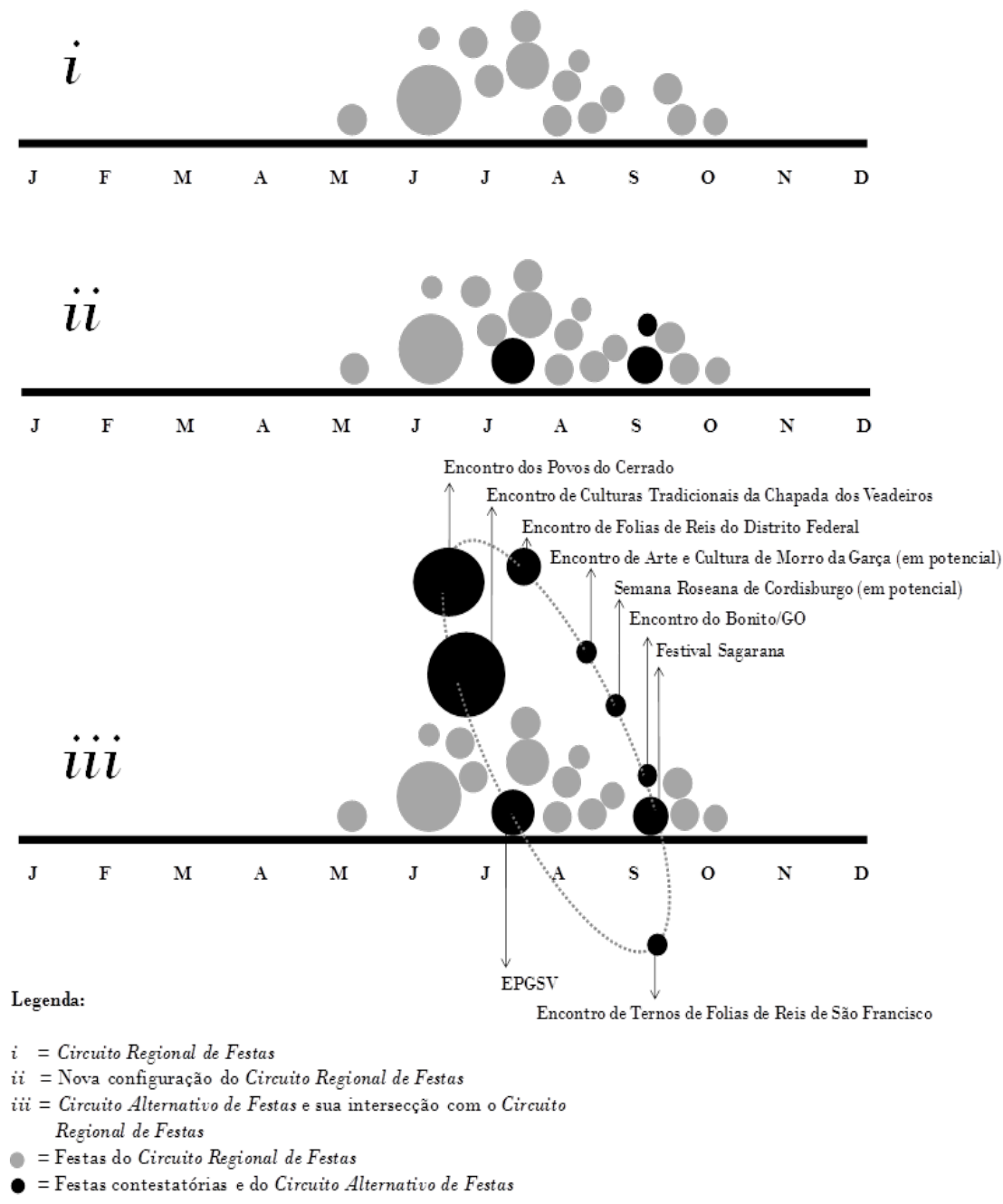

Figura 4 - Intersecção entre o 'Circuito Regional de Festas' e o 'Circuito Alternativo de Festas'. Fonte: o autor. 
A ideia de transição que emana dessa dinâmica, entretanto, esbarra exatamente no elemento 'novidade' que se buscava instituir. Esbarra porque há ressonância entre o modus operandi das prefeituras e as expectativas locais do 'povo' - poder-se-ia questionar 'por que os modos personalistas se estendem no tempo?', 'em que medida eles são reproduzidos como signos culturais?'. Ou seja, as prefeituras, se comparadas com as ações da rede contestatória, aparecem mais bem dialogando com o 'povo', a partir de um jogo provimento-expectativas. Expectativas que se mostram em movimento e que as prefeituras parecem dar conta de alcançar, a exemplo dos signos da cultura de massas; sempre em renovação ${ }^{30}$, mas que não deixam de ser 'ofertados' por elas. Conforme pontuou Kuschnir "a política opera com valores da sociedade mais abrangente, tradicionalmente associados a outras esferas da vida social" (2007:165). O que parece não se renovar, no entanto, é o ato de prover em si. Atualiza-se, então, o 'fazendeiro'-'patrão', na figura do prefeito, o 'pai de todos', financiando festas, realizando favores relacionados à saúde, elegendo pessoaschave, estabelecendo hierarquias etc. Para Chaves (2003), é sempre mais fácil eleger-se pelos iguais.

Essa ressonância personalismo-'povo' evidencia um dos limites das desestabilizações provocadas pelas festas político-culturais de caráter contestatório representadas na figura acima. Grosso modo, esses eventos parecem causar ao 'povo' mais estranhamento que estabilidade e nem sempre forjam as solidariedades esperadas. Por outro lado, sustentam uma espécie de aliança com a 'tradição', por sua vez percebida como 'cultura', ou melhor, como a porção dela intimidada pelo tempo e pelas dinâmicas modernizantes que se desdobram ali. A 'cultura de tradição', sendo objeto de enaltecimento nos eventos contestatórios, é também percebida como elemento menosprezado pelas prefeituras, de forma tal que determinados gestores culturais - os 'fazedores de cultura', ou seja, detentores e mestres de determinadas manifestações culturais ali, a exemplo do 'São Gonçalo', da 'catira', da 'caninha verde', da 'fiação' - demonstram reflexividade acerca 
do papel que a 'área da cultura' deveria exercer: para além das festas massificantes. Isso parece conformar um dos pontos de partida para a construção de alianças entre estes 'fazedores de cultura', por exemplo, e representantes da rede contestatória - e mesmo para a pertença à rede. Em um plano mais amplo, identifica-se na rede contestatória o questionamento do modelo de desenvolvimento em curso, não sem contradições. Se Chaves (2003) observou que o desenvolvimento econômico era consenso nas festas em Buritis, no território ArinosChapada o desenvolvimento surge como objeto de disputa. Em ressonância, o próprio modelo personalista é problematizado no curso das ações do campo artístico-cultural ali.

"O importante é que, nessas lutas moleculares, estão sendo experimentadas formas de ruptura com o modo de funcionamento da política que é tão velho quanto o Brasil oficial. Não são ataques externos, mas ataques internos às vezes muito profundos, embora sem batalhas finais, porque não há vitórias definitivas e o sucesso dessas experiências também geram problemas a serem enfrentados, mas que ajudam a descobrir caminhos novos de enfrentamento, que não têm por que continuar sendo simplesmente locais" (Palmeira 2006:149).

No território Arinos-Chapada, para além de haver uma 'época da política', esta política se faz também na 'área da cultura', em festas que revelam um conteúdo de signos, valores, operações regionais, enfim, noções próprias de política conferidas pelos atores sociais. Daí que o aparato moderno e as representações de desenvolvimento são mais bem interpretados, por um lado, à luz da recorrência de mecanismos empregados já há bastante tempo, a exemplo do personalismo e do movimento, ao posso que, por outro lado, a ação de atores locais deve ser entendida no plural, porque é nutrida de valores distintos, em algum grau antagônicos, que encerram por revelar, por exemplo, 'políticas culturais'. Essa pluralidade parece ganhar relevância quando fica em jogo projetos de mundo - de desenvolvimento -, algo que envolve a construção ativa e reflexiva de perspectivas por parte desses agentes. Interesses conflitantes, então, forjam coalizões em cena e geram 
complexidade, por sua vez acrescida de mensagens advindas de um modelo ocidental de desenvolvimento - racional, legal, burocrático e produtivista, a exemplo da PEPAC-MG -, criando tensões, mas não sem que haja a capacidade de reposicionamento por parte de atores locais em processos de mudança social ou de reorientação da realidade. Se parte dos atores desta trama legitima suas ações valendo-se de certos costumes e de modus operandi 'já estabelecidos', outra parte acresce ou modifica este modus quando adentra as festas, produzindo estranhamentos e desestabilizações no status quo.

\section{Notas:}

1 'Sertão' em geral não faz referência a uma categoria nativa identitária. Recorro a ela porque estou a tratar de um conjunto de agentes sociais com múltiplas referências de localização. Coincide que Arinos, um dos municípios em questão, é reconhecido como sendo do noroeste de Minas Gerais, ao passo que Chapada Gaúcha da porção norte. Sertão aparece ali como uma categoria nativa adotada prevalentemente em um sentido estratégico; adoto-a aqui oportunamente, em um sentido unificador, para poder referenciar uma diversidade de grupos sociais de 'porções territoriais contíguas'.

2 Para maiores detalhes sobre o percurso metodológico que empreendi para escolher um local de estudo nessa perspectiva, ver Meyer (2019:29-74). De um modo geral, busquei por regiões que tivessem municípios contíguos com menos de 20.000 habitantes que tivessem Pontos de Cultura. Esse foi um critério inicial que indicaria a possibilidade de alguma 'efervescência' artístico-cultural política em interface com o 'mundo rural'.

3 O conteúdo empírico ao qual recorro foi extraído da etnografia que mencionei no início, na qual me vali de conversas informais, entrevistas abertas e semi-estruturadas e de observação participante.

4 O termo 'circuito regional de festas' não é exatamente local; trata-se da forma encontrada para representar a dinâmica de festas de um 'tempo de festas', considerando, para além de Arinos e Chapada Gaúcha, uma região maior.

5 Neste caso, faço referência, por exemplo, aos chamados 'grandes shows sertanejos', com artistas do circuito comercial de música, amplamente conhecidos e representantes do mainstream artístico-cultural. Observam-se, associados: o consumo banalizado de bebidas alcoólicas, as apresentações de artistas excessivamente midia- 
tizados (em muitos casos, desempenhando músicas cujas letras são sexualizadas), o alto volume sonoro e a presença predominante de jovens.

6 A Figura 1 foi elaborada, em grande medida, a partir de informações fornecidas por alguns desses comerciantes, residentes em Chapada Gaúcha. Também pela observação de cartazes afixados em pontos diversos, principalmente em Arinos.

7 Destaco que a representação nela sistematizada não encerra todo o conjunto de festas da região, tampouco ela é exata no que se refere à significância de cada uma dessas festas em relação às demais (representada pelo tamanho dos círculos). Desta feita a figura foi elaborada com intuito elucidativo.

8 É assim que os conteúdos de uma 'cultura de massas' não são exclusivos do circuito regional de festas. Ao contrário, esse circuito aparece como espaço onde se abrigam, se reproduzem e se modificam esses conteúdos.

9 Nesse sentido, foi amplamente relatado que as folias são realizadas principalmente por ex-residentes da região, que se deslocam ao local de origem para, a cada ano, consagrá-la, em cumprimento de promessa, para revisitar parentes e amigos, para festejar etc.

10 Comunidade dos Buracos, ou Vão dos Buracos, local de estudo da autora, muito próximo à sede municipal de Chapada Gaúcha (aprox. $10 \mathrm{~km}$ ).

11 Para uma iniciação nesse assunto, ver Dayrell 1998.

12 Na prática, a melhor forma de se entender 'movimento' é perguntando sobre as trajetórias de vida de residentes antigos da região. Essas trajetórias estarão repletas de deslocamentos de residência pela região e pelo país.

13 Termo emprestado de Chaves (2003).

14 'Agregado', faz referência à divisão social 'fazendeiros'-'agregados', na qual os primeiros agiam como provedores e sediam terras aos segundos, numa relação de favores assimétrica. De um modo geral, tal divisão teria vigorado até o início da modernização da agricultura ali.

15 A 'época das fazendas' é aquela onde se estabeleciam relações entre 'fazendeiros' e 'agregados', marcada pela 'cessão' de terras por parte dos primeiros aos segundos. 16 Apesar disso, há que se considerar que o 'tempo da política' manifesta uma dinâmica própria marcada pelas campanhas eleitorais propriamente ditas, algo que nos leva a diferenciar a política que se faz no 'tempo da política' e aquela que se revela nas 'festas das cidades', ou seja, cada uma parece ter um movimento próprio, ainda que se possam vislumbrar continuidades.

17 Vale ressaltar que a gratuidade é categoria explorada também no âmbito da rede de atores contestatórios, de modo reflexivo. As ações dessa rede serão exploradas mais à frente.

18 Trata-se de fenômeno marcante em alguns contextos rurais contemporâneos, decorrente do êxodo rural seletivo, por parte de mulheres que migram às sedes municipais em busca de estudo ou trabalho mais privilegiado. Neste sentido, ver Weisheimer (2004). 
19 Ao longo da pesquisa de campo interessei-me pela questão da ocorrência das festas como espaços para estes relacionamentos. Buscava, creio que em demasia, uma justificativa estruturante para as festas, particularmente em relação à adesão de jovens ao funk, entre outras questões. Cheguei, inclusive, a entrevistar alguns jovens, buscando apreender suas trajetórias e impasses. De um modo geral, deparei-me com a diversidade de significados aí envolvidos e com as marcas dos regramentos morais, da masculinização e da intensa circulação de valores que, grosso modo, remetiam à cultura de massas.

20 Os Pontos de Cultura correspondem a projetos artístico-culturais propostos por organizações locais diversas (em geral ONGs e prefeituras), a partir de editais públicos federais e estaduais. À época de 2013, esses projetos em geral tinham duração de três anos e valor orçamentário total de $\mathrm{R} \$ 180.000,00$.

21 Poderia se estar incluindo aqui ainda outros municípios das redondezas.

22 O IEPHA dá a orientação para que os municípios instituam um programa permanente de educação patrimonial, visando principalmente dar visibilidade à dimensão do patrimônio cultural junto à população. $\mathrm{O}$ município que institui e mantém esse programa consegue maiores pontuações junto ao ICMS-PC.

23 Observa-se, por exemplo, um folder do Ministério Público Federal intitulado Patrimônio cultural é de todos. Nesse documento, ao se tentar explicar a abrangência do patrimônio cultural em 11 itens, 10 foram reservados à exposição da dimensão material, ao passo que apenas um à dimensão imaterial. Situação particular em que os números auxiliam a revelar visões.

24 Para uma compreensão aprofundada sobre a tessitura dessas alianças, ver Meyer (2019).

25 Aqui não se enfatiza exatamente alguma ilegalidade, mas, em última instância, a flexibilidade do que pode ser alocado na 'área da cultura' e o contexto em que isto é realizado, acionando arranjos particulares entre cultura e contingências que trato aqui em termos de 'novo'. Também, demonstra a alienação acerca de qualquer filosofia que oriente as políticas culturais que se desdobram no âmbito municipal, a despeito de direcionamentos formulados segundo uma ordem homogeneizante superior, estadual.

26 Friso que os gastos com festas apresentados no Quadro 1 não correspondem aos gastos totais em festas. Primeiro, porque as festas estão ligadas diretamente com duas secretarias, a de cultura e a de esporte e lazer. Segundo, porque não quer dizer que o montante gasto em determinada festa venha exclusivamente dessas secretarias, considerando que os gastos podem ser divididos em rubricas de empenho diversas. E há também a capacidade instalada da prefeitura. A destinação de funcionários, veículos etc., às festas não necessariamente é contabilizada nos gastos oficiais.

27 Para Vasconcelos \& Santos, “os Espaços Mais Cultura são a concretização da proposta de implantação ou ampliação de centros culturais, espaços de exposição, teatros, cinemas, bibliotecas, salas de leitura e espaços multifuncionais nas periferias e em sítios centrais da cidade, de forma a assegurar áreas de convívio, lazer e atividade física e promover a qualidade de vida e vivência cultural das populações locais. De acordo com o documento explicativo sobre o Mais Cultura, o Programa 
estabelecerá uma política de programação dos Espaços investindo na circulação e na seleção qualificada das ações culturais, na capacitação de gestores e na formação e ampliação do público acolhido por esses espaços" (2010:91).

28 Trata-se de uma política cultural governamental de cunho popularizante e voltado, segundo as premissas do próprio programa, a garantir o acesso aos bens culturais por parte das comunidades historicamente excluídas. Nesse sentido, ver IPEA (2011:174).

29 A respeito disso, é importante frisar que a maior parte das festas do circuito regional de festas inscritas no território que inclui e circunda Arinos e Chapada Gaúcha sinalizava custar muitas vezes mais do que o valor dessas contrapartidas. A 'festa da Serra', por exemplo, contratou em 2013 'artistas' de circulação nacional, como 'Gasparzinho', 'Di Paullo \& Paulinho', 'Forró Boys', 'Edimilson Batista', 'Forró Sapeká', entre muitos outros.

30 Se há predileções pela mudança, por exemplo, estética (como as vestimentas e as formas de apresentação dos shows), de modo a incorporar trejeitos 'roliudianos' e sertanejos em transformação, há resistência a determinadas mudanças mais estruturantes. A resistência é frequentemente expressa em termo de preconceito; o desconhecido é visto como ameaça.

\section{Referências:}

ANDRIOLLI, Carmen S. 2011. Sob as vestes de Sertão Veredas, o Gerais: 'Mexer com criação' no Sertão do IBAMA. Tese de Doutorado. Campinas: Universidade Estadual de Campinas.

ARCE, Alberto. 2003. "Re-approaching social development: a field of action between social life and policy processes". Journal of International Development, 15(7):845-861.

ARCE, Alberto \& LONG, Norman (eds.). 2000. Anthropology, Development and Modernities: exploring discourses, counter-tendencies and violence. London: Routledge.

BRANDÃO, Carlos R. 1981. Sacerdotes da Viola. Petrópolis: Vozes.

CANCLINI, Néstor G. 2011. Culturas Híbridas: estratégias para entrar e sair da modernidade. São Paulo: Editora da Universidade de São Paulo.

CERQUEIRA, Ana C. 2010. O 'povo' parente dos Buracos: mexida de prosa e cozinha no cerrado mineiro. Tese de Doutorado. Rio de Janeiro: Universidade Federal do Rio de Janeiro.

CHAVES, Christine. 2003. Festas da política: uma etnografia da modernidade no sertão (Buritis - MG). Rio de Janeiro: Relume Dumará.

DAINESE, Graziele. 2016. "Movimento e animação das festas, visitas, andanças e chegadas". Mana, 22(3):641-669. 
DAYRELL, Carlos Alberto. 1998. Geraizeiros e biodiversidade no norte de Minas: a contribuição da agroecologia e da etnoecologia nos estudos do agrossistemas tradicionais. Dissertação de Mestrado. Huelva: Universidade Internacional de Andalucia.

DE VRIES, Pieter. 2007. "Don't Compromise Your Desire for Development! A Lacanian/Deleuzian Rethinking of the Anti-Politics Machine”. Third World Quarterly, 28(1):25-43.

ESCOBAR, Arturo. 1995. Encountering Development. Princeton: Princeton University Press. . 1998. La Invención del Tercer Mundo: construcción y deconstrucción del desarrollo. Santafé de Bogotá: Norma.

FAIRHEAD, James. 2000. "Development discourse and its subversion: decivilisation, depoliticisation and dispossession in West Africa”. In ARCE, A. \& LONG, N. (eds.): Anthropology, Development and Modernities: exploring discourses, counter-tendencies and violence, pp. 100-111. London: Routledge.

FJP (Fundação João Pinheiro). 2014. Lei Robin Hood. (www.fjp.mg.gov.br/robinhood/index.php/transferencias/pesquisa municipio; acesso em 11/12/2014).

GOLDMAN, Marcio. 2006. Como Funciona a Democracia: uma teoria etnográfica da política. Rio de Janeiro: 7 Letras.

IBGE. 2007. Perfil dos municipios brasileiros: cultura - 2006. Rio de Janeiro: IBGE.

IEPHA/MPMG. 2011. Fundo Municipal de Proteção ao Patrimônio Cultural: Importância, criação e gestão. Belo Horizonte: MPMG.

IPEA. 2011. Cultura Viva: as práticas de pontos e pontões. Brasília: IPEA.

KUSCHNIR, Karina. 2007. "Antropologia e Política”. Revista Brasileira de Ciências Sociais, 22(64):163-167.

LONG, Norman. 2007. Sociología del Desarrollo: una perspectiva centrada en el actor. Ciudad de México: Centro de Investigaciones y Estudios Superiores em Antropología Social.

MEYER, Gustavo. 2019. Quando Arte e Cultura Falam em Desenvolvimento: atores sociais e experiências no mundo rural do noroeste mineiro. Curitiba: Appris.

MEYER, G., MARQUES, F. \& BARBOSA, G.. "Entidades performáticas e desestabilização: o desenvolvimento local para além do mainstream”. Interações, 17(1):33-45.

MINAS GERAIS. 2000. Lei No 13.803, de 27 de dezembro de 2000. (www.fjp. mg.gov.br/robin-hood/index.php/leirobinhood/legislacao/lei1380300; acesso em 13/12/2013).

PALMEIRA, Moacir. 2002. "Política e tempo: nota exploratória”. In PEIRANO, Mariza (ed.): O Dito e o Feito: Ensaio de antropologia dos rituais, pp. 171-177.

Rio de Janeiro: Relume-Dumará. 
PALMEIRA, Moacir. 2006. "Eleição municipal, política e cidadania". In PALMEIRA, M. \& BARREIRA, C. (eds.): Politica no Brasil, pp. 137-150. Rio de Janeiro: Relume Dumará.

PALMEIRA, Moacir \& BARREIRA, Cesar. 2006. "Introdução”. In PALMEIRA, M. \& BARREIRA, C. (eds.): Politica no Brasil, pp. 9-22. Rio de Janeiro: Relume Dumará.

PALMERA, Moacir \& HEREDIA, Beatriz. 1995. "Os comícios e a política de facções”. Anuário Antropológico, 19(1):31-94.

PAULA, Silvana. 2001. "Quando o campo se torna uma experiência urbana: o caso do estilo de vida country no Brasil". Estudos Sociedade e Agricultura, 17:33-53.

PEIRANO, Marisa. 1997. "Antropologia política, ciência política e antropologia da política”. Série Antropologia (UnB), 231:15-26.

PEREIRA, Luzimar P. 2009. Os Giros do Sagrado: um estudo etnográfico sobre as folias em Urucuia - MG. Tese de Doutorado. Rio de Janeiro: Universidade Federal do Rio de Janeiro.

PMA (Prefeitura Municipal de Arinos). 2013. Contas Públicas. (www.arinos.mg.gov. br/contas-publicas.html; acesso em 13/12/2013).

PMCG (Prefeitura Municipal de Chapada Gaúcha). 2013a. Despesas por unidade e dotação: município de Chapada Gaúcha: 2013. Chapada Gaúcha: PMCG. 2013b. Orçamento por programa: município de Chapada Gaúcha: 2013. Chapada Gaúcha: PMCG. . 2013c. Quadro IV: investimentos financeiros com recursos do Fundo Municipal do Patrimônio Cultural em Bens Protegidos (2013). Chapada Gaúcha: PMCG.

RIBEIRO, Gustavo L. 2008. "Poder, redes e ideologia no campo do desenvolvimento". Novos Estudos (CEBRAP), 27(1):109-125.

SILVA, Rodrigo M. 2014. "As políticas culturais brasileiras na contemporaneidade: mudanças institucionais e modelos de agenciamento". Revista Sociedade e Estado, 29(1):199-224.

VASCONCELOS, Ana T. \& SANTOS, Juliana. 2010. "Os espaços Mais Cultura e a Funarte: política pública como ferramenta de criação e difusão cultural". Liinc em Revista, 6(1):89-100.

WEISHEIMER, Nilson. 2004. Os jovens agricultores e seus projetos profissionais: um estudo de caso no bairro de Escadinhas, Feliz/RS. Dissertação de Mestrado. Porto Alegre: Universidade Federal do Rio Grande do Sul.

Abstract: From the view of the anthropology of politics and of development, I analyze some linkages between the 'area of culture', politics and policies and development in the municipalities of Arinos and Chapada Gaúcha, Minas Gerais. Cultural elements, such as 'movement' and 'personalism', participate as guidelines for heterogeneous local actors - with 
competing interests, worldviews and future projects - to operate a party circuit, appealing to distinct cultural public policies to hold agency and dueling senses in the 'area of culture'. The power of some to subvert - provoking a depoliticization-agency tension - and the ability of others to weave supralocal alliances and innovate through networked articulations are mediated by policies, which impose particular rationality, but also provide important resources for dispute. From this sort of game, one can perceive the multiplicity of the state itself, which combined with local counter-actions, opens up potential space for power redistribution.

Keywords: Social change, Cultural policy, Development, Anthropology of politics.

Recebido em Maio de 2019.

Aprovado em Julho de 2019. 